\title{
STUDI ETNOBOTANI TUMBUHAN BERKHASIAT OBAT YANG DIMANFAATKAN MASYARAKAT SUKU MELAYU KABUPATEN LINGGA KEPULAUAN RIAU
}

\author{
Etnobotanical Study of Medicinal Plants for Used by Malay People in Lingga \\ District the Kepulauan Riau Province \\ Ufara Qasrin ${ }^{1 *}$, Agus Setiawan ${ }^{1}$, Yulianti $^{1}$, Afif Bintoro ${ }^{1}$ \\ 'Jurusan Kehutanan, Fakultas Pertanian, Universitas Lampung \\ Jln. Prof. Dr. Soemantri Brojonegoro No. 1 Gedung Meneng, Bandar Lampung \\ *Email: qasrinufara@gmail.com
}

Direvisi: 19/06/2020, Diterbitkan: 01/08/2020

\begin{abstract}
.
Medicinal plants have long been used by traditional communities, one of them is the Malay people in Lingga Regency, Riau Islands Province in healing various diseases. This study aims to determine the types of medicinal plants based on local knowledge of the indigenous Malay people. The population of this research is the native Malay people of Lingga Regency and the sampling is done using the snowball sampling method so that the selected respondents are following the required data. This type of research is descriptive research with qualitative and quantitative methods. The qualitative method was used to find out the use of medicinal plants used by the community by interview while the quantitative method was used to find out the percent of the use of medicinal plants by the Malays from the interviews. Based on the results of the study there were 102 types of medicinal plants in 53 families. The most commonly used plant parts are leaves (45.10\%) by boiling and the least used are seeds and bark (1.96\%). The most used habitats were herbs (27.45\%) and trees $(26.47 \%)$ and the least used were liana (8.82\%) and terna (3.92\%). Diseases that are usually treated by people with plants are diseases that are commonly suffered by ordinary people such as fever, diarrhea, coughing, toothaches, itching and mouth sores.
\end{abstract}

Keywords; Ethnobotany, local knowledge, Malay tribe, medicinal plants

\begin{abstract}
ABSTRAK
Tumbuhan yang berkhasiat obat telah lama digunakan oleh masyarakat tradisional dalam penyembuhan berbagai penyakit, salah satunya masyarakat Suku Melayu di Kabupaten Lingga Provinsi Kepulauan Riau. Penelitian ini bertujuan untuk mengetahui jenis tumbuhan yang berkhasiat obat berdasarkan pengetahuan lokal masyarakat adat Suku Melayu. Populasi peneltian ini adalah masyarakat Suku Melayu asli Kabupaten Lingga dan pengambilan sampel dilakukan dengan menggunakan metode snowball sampling, sehingga responden yang terpilih sesuai dengan data yang diperlukan. Jenis penelitian ini adalah penelitian deskriptif dengan metode kualitatif dan kuantitatif. Metode kualitatif digunakan untuk mengetahui penggunaan tumbuhan obat yang digunakan masyarakat dengan cara wawancara sedangkan metode kuantitatif digunakan untuk mengetahui banyaknya penggunaan tumbuhan obat oleh masyarakat Suku Melayu dari hasil wawancara. Berdasarkan hasil penelitian terdapat 102 jenis tumbuhan berkhasiat obat dari 53 famili. Bagian tumbuhan yang paling sering digunakan adalah daun $(45,10 \%)$ dengan cara pengolahan direbus dan yang paling sedikit digunakan adalah biji dan kulit (1,96\%). Habitus yang paling banyak digunakan adalah herba $(27,45 \%)$ dan pohon $(26,47 \%)$ dan yang paling
\end{abstract}


sedikit digunakan adalah liana $(8,82 \%)$ dan terna (3,92\%). Penyakit yang biasanya diobati oleh masyarakat dengan tumbuhan adalah penyakit yang umumnya sering diderita oleh masyarakat awam seperti demam, diare, batuk, sakit gigi, gatal-gatal dan sariawan.

Kata kunci; Etnobotani, pengetahuan lokal, Suku Melayu, tumbuhan berkhasiat obat

\section{PENDAHULUAN}

Indonesia merupakan negara yang memiliki tingkat keanekaragaman hayati yang tinggi. Salah satunya adalah potensi tumbuhan obat yang belum teridentifikasi keberadaannya terutama pada hutan tropis. (Syaifuddin dkk, 2015). Kepulauan Riau merupakan salah satu pulau di Indonesia yang terkenal akan sumber daya alam yang dimilikinya. Kekayaan akan wawasan pengobatan tradisional dengan tumbuhan yang diwariskan secara lisan, dari generasi ke generasi yang belum tersampaikan pada masyarakat Indonesia. Pengetahuan tersebut tidak terdokumentasi sehingga sulit dipublikasikan secara luas. Ketidakpedulian masyarakat terhadap pengetahuan ini akan menyebabkan hilangnya habitat alami dengan punahnya tumbuhan berkhasiat obat terutama tumbuhan hutan akibat eksploitasi dan konversi lahan.

Seiring meningkatnya perkembangan ilmu pengetahuan, teknologi dan ekonomi di Indonesia, generasi muda secara umum tidak lagi tertarik pada seni dan pengetahuan tradisional. Ilmu ini dianggap sudah absolut dan tidak laku lagi di zaman globalisasi sekarang ini (Purwanti, 2017). Generasi muda sekarang sangat kurang berminat untuk mempelajari pengetahuan pengobatan tradisional dengan memanfaatkan tumbuhan dan hal ini dapat menjadikan warisan tradisional ini yang lambat laun akan punah. Menurut Supriyanto (2014) masyarakat lebih tertarik untuk menggali potensi hutan dari sisi potensi kayu dibandingkan dengan nir-kayu.

Tumbuhan obat merupakan tumbuhan yang bisa diambil manfaatnya sebagai obat herbal yang mempunyai kandungan yang berkhasiat obat dan penggunaannya tidak berbahaya untuk tubuh kita. Sejalan dengan pendapat Farida (2012) bahwa tanaman obat memiliki keunggulan lebih dari obat biasa, karena memiliki kemampuan untuk memperbaiki aktivitas biomolekuler tubuh. Tanaman obat bukan hanya mengobati tetapi juga menyembuhkan. Tanaman obat memiliki kemampuan memperbaiki keseluruhan sistem, karena bekerja dalam lingkup sel molekuler.

Pengetahuan tentang obat-obatan tradisional sangat sedikit diketahui dan biasanya hanya disampaikan secara turun temurun, serta sulit disampaikan secara bebas. Sabri (2011) mengatakan dukun kampung yang mempunyai pengetahuan tentang pengobatan tradisional umumnya sudah berumur 50 tahun sehingga dikhawatirkan tidak ada generasi penerus yang memahami tentang pengobatan tradisional dan akibatnya kesinambungan penggunaan obat tradisional yang sudah digunakan akan dilupakan. Susiarti (2005) menjelaskan bahwa pengetahuan tradisional akan hilang dengan semakin intesifnya tekanan faktor tersebut. Hal ini dapat dibuktikan dengan semakin banyaknya penggunaan obat modern yang lebih banyak dipilih karena lebih praktis dan relatif mudah didapat. Tujuan penelitian ini adalah untuk mengetahui bagaimana kearifan masyarakat suku melayu dalam memanfaatkan tumbuhan dan mengetahui jenis tumbuhan obat yang digunakan oleh masyarakat Suku Melayu di Kabupaten Lingga Provinsi Kepulauan Riau.

\section{METODE}

Penelitian dilaksanakan pada bulan Januari-Februari 2020 di sekitar kawasan hutan Kabupaten Lingga Kepulauan Riau yaitu Pulau Singkep pada lima desa yaitu Desa Batu Berdaun, Tanjung Harapan, Lanjut, Kampung Boyan dan Kebun Nyiur. Alat yang digunakan dalam penelitian ini antara lain Alat Tulis Kerja (ATK), kamera, tape recorder, laptop dan objek penelitian adalah semua jenis tumbuhan yang dimanfaatkan masyarakat 
suku Melayu sebagai obat. Responden dipilih menggunakan metode snowball sampling (Poerwandari, 2001).

Responden yang dipilih adalah masyarakat asli Suku Melayu yang memiliki pengetahuan lokal tentang pemanfaatan tumbuhan. Pencatatan dilakukan untuk mengetahui jenis tumbuhan yang biasa digunakan sebagai obat oleh masyarakat. Pengambilan data terhadap responden minimal 25 orang, tetapi apabila data yang terkumpul sudah cukup pengambilan data dihentikan sehingga pada saat pelaksanaan pengambilan data didapatkan responden mencukupi 25 orang (Rijaii, 2011). Data wawancara hasil dan pengamatan tumbuhan berkhasiat obat dianalisis sehingga memperoleh gambaran seperti jenis tumbuhan, famili, bagian yang digunakan dan manfaat tumbuhan tersebut. Peta lokasi penelitian dapat dilihat pada Gambar 1.

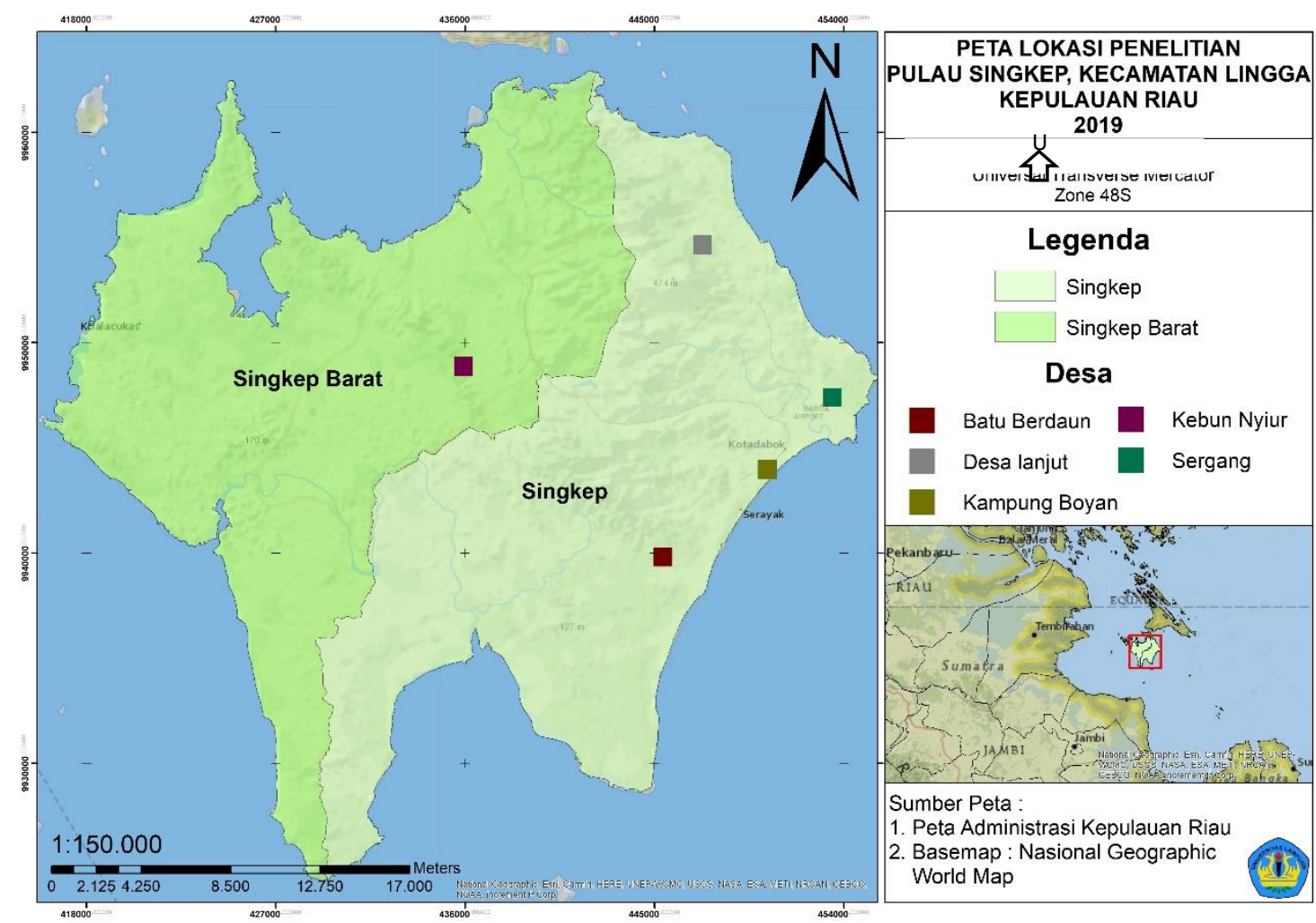

Gambar 1. Peta lokasi penelitian.

Figure 1. Map of research location

Analisis data penelitian ini menggunakan metode kualitatif dan kuantitatif dengan jenis penelitian deskriptif. Menurut Nawawi dalam Hidayat (2009), penelitian deskriptif yaitu memusatkan perhatian pada masalah-masalah yang ada pada saat penelitian dilakukan atau masalah yang bersifat aktual dan menggambarkan fakta-fakta tentang masalah yang diselidiki. Metode kualitatif digunakan untuk mengetahui penggunaan tumbuhan yang berkhasiat obat oleh masyarakat Suku Melayu, sedangkan metode kuantitatif digunakan untuk mengetahui persentase dari penggunaan tumbuhan berkhasiat obat oleh masyarakat. Perhitungan yang dilakukan memperlihatkan jumlah habitus dan bagian tumbuhan terbanyak dan paling sedikit yang digunakan. Analisis persen habitus ataupun bagian tumbuhan yang digunakan menggunakan rumus sebagai berikut (Fakhrozi, 2009):

$\%$ Habitus tertentu $=\sum$ Jumlah seluruh spesies $\quad \times 100 \%$

$\%$ Bagian tumbuhan $=\frac{\sum \text { bagian tumbuhan yang digunakan }}{\sum \text { seluruh bagian yang digunakan }} \times 100 \%$ 


\section{HASIL DAN PEMBAHASAN}

Masyarakat Kabupaten Lingga Provinsi Kepulauan Riau sebagian besar adalah Suku Melayu. Suku ini di biasanya memanfaatkan tumbuh-tumbuhan untuk pengobatan tradisional dalam kehidupan sehari-hari atau biasa disebut etnobotani. Kebiasaan masyarakat terhadap tumbuhan berkhasiat obat untuk pengobatan tradisional merupakan kepercayaan turun temurun. Setiap responden memiliki cara tersendiri dalam penggunaan tumbuhan berkhasiat obat untuk menyembuhkan berbagai jenis penyakit dan cara penggunaannya dilakukan dengan pengalaman yang dilihat dari keluarga atau saudara terdekat.

Jenis tumbuhan yang dimanfaatkan oleh masyarakat Suku Melayu sebagai obat dikelompokkan kedalam 53 famili, dengan jumlah spesies yang terbanyak yaitu 11 spesies dan jumlah terkecil yaitu 1 spesies yang dapat dilihat pada Tabel 1.

Tabel 1. Persentase penggunaan jenis tumbuhan obat berdasarkan famili Table 1. Percentage of use medicinal plant species by family

\begin{tabular}{|c|c|c|c|}
\hline No & Famili & Jumlah & Persentase (\%) \\
\hline 1 & Acanthaceae & 3 & 2.941 \\
\hline 2 & Agavaceae & 1 & 0.980 \\
\hline 3 & Alliaceae & 2 & 1.961 \\
\hline 4 & Amaranthaceae & 1 & 0.980 \\
\hline 5 & Anacardiaceae & 1 & 0.980 \\
\hline 6 & Annonaceae & 2 & 1.961 \\
\hline 7 & Anthericaceae & 1 & 0.980 \\
\hline 8 & Apiaceae & 1 & 0.980 \\
\hline 9 & Apocynaceae & 2 & 1.961 \\
\hline 10 & Arecaceae & 1 & 0.980 \\
\hline 11 & Asteraceae & 7 & 6.863 \\
\hline 12 & Baselaceae & 1 & 0.980 \\
\hline 13 & Brassicaceae & 1 & 0.980 \\
\hline 14 & Caricaceae & 1 & 0.980 \\
\hline 15 & Combretaceae & 1 & 0.980 \\
\hline 16 & Commelinaceae & 1 & 0.980 \\
\hline 17 & Convolvulaceae & 1 & 0.980 \\
\hline 18 & Crassulaceae & 1 & 0.980 \\
\hline 19 & Dryopteridaceae & 1 & 0.980 \\
\hline 20 & Euphorbiaceae & 4 & 3.922 \\
\hline 21 & Fabaceae & 5 & 4.902 \\
\hline 22 & Fagaceae & 1 & 0.980 \\
\hline 23 & Gnetaceae & 1 & 0.980 \\
\hline 24 & Lamiaceae & 5 & 4.902 \\
\hline 25 & Lauraceae & 2 & 1.961 \\
\hline 26 & Liliaceae & 3 & 2.941 \\
\hline 27 & Loranthaceae & 1 & 0.980 \\
\hline No & Famili & Jumlah & Persentase (\%) \\
\hline 28 & Mackinlayaceae & 1 & 0.980 \\
\hline 29 & Malfaceae & 2 & 1.961 \\
\hline 31 & Menispermaceae & 1 & 0.980 \\
\hline 32 & Moraceae & 1 & 0.980 \\
\hline 33 & Myristicaceae & 1 & 0.980 \\
\hline 34 & Myrtaceae & 6 & 5.882 \\
\hline 35 & Nyctaginaceae & 1 & 0.980 \\
\hline 36 & Oleaceae & 1 & 0.980 \\
\hline 37 & Orchidaceae & 1 & 0.980 \\
\hline
\end{tabular}




$\begin{array}{llcc}38 & \text { Oxalidaceae } & 1 & 0.980 \\ 39 & \text { Phyllanthaceae } & 1 & 0.980 \\ 40 & \text { Piperaceae } & 4 & 3.922 \\ 41 & \text { Poaceae } & 2 & 1.961 \\ 42 & \text { Polygonaceae } & 2 & 1.961 \\ 43 & \text { Portulacaceae } & 1 & 0.980 \\ 44 & \text { Ranunculaceae } & 1 & 0.980 \\ 45 & \text { Rosaceae } & 1 & 0.980 \\ 46 & \text { Rubiaceae } & 3 & 2.941 \\ 47 & \text { Rutaceae } & 2 & 1.961 \\ 48 & \text { Santalaceae } & 1 & 0.980 \\ 49 & \text { Sapindaceae } & 1 & 0.980 \\ 50 & \text { Selaginelle } & 1 & 0.980 \\ 51 & \text { Simaroubaceae } & 1 & 0.980 \\ 52 & \text { Thymelaeaceae } & 1 & 0.980 \\ 53 & \text { Zinggiberaceae } & 11 & 10.784\end{array}$

Sumber: Data primer (2020)

Suku tumbuhan dari yang terbanyak digunakan terdapat pada suku Zingiberaceae (11 jenis), Asteraceae (7 jenis), Myrtaceae (6 jenis), Lamiaceae, Fabaceae (5 jenis), Piperaceae, Euphorbiaceae (4 jenis), Acanthaceae, Liliaceae, Rubiaceae (3 jenis), Alliaceae, Annonaceae, Apiaceae, Lauraceae, Malfaceae, Poaceae, Polygonaceae, Rutaceae (2 jenis) serta suku tumbuhan lainnya yang memiliki 1 jenis tumbuhan. Cowan (1999) mengatakan suku tumbuhan Zingiberaceae banyak digunakan karena jenis-jenis tanaman dari suku tersebut sangat familiar di kalangan masyarakat umumnya seperti jahe, kunyit, kencur, temulawak, temu ireng, dan lengkuas. Salah satunya adalah jenis temulawak (Curcuma xanthorrhiza), temulawak merupakan satu dari 19 jenis temutemuan keluar Zingiberaceae yang banyak digunakan sebagai bahan baku obat tradisional. Menurut Mayangsari (2019) Tumbuhan temulawak dari suku zingiberaceae merupakan tumbuhan obat yang dapat mengobati penyakit infeksi. Temulawak juga dapat memberikan efek antimikroba karena kandungan bahan aktif berupa minyak atsiri. Salah satu unsur minyak atsiri yaitu terpenoid yang diduga melibatkan pemecahan membran oleh komponen-komponen lipofilik.

102 spesies tumbuhan diketahui berkhasiat sebagai obat-obatan. Jenis tumbuhan yang diketahui oleh masyarakat Suku Melayu adalah tumbuhan yang memang sudah sering digunakan dari generasi ke generasi sehingga masyarakat masih menggunakan tumbuhan tersebut sebagai kebutuhan sehari-hari saat sedang mengalami sakit. Tumbuhan digunakan untuk mengobati berbagai macam penyakit yang sering terjadi pada masyarakat diantaranya penyakit demam, masuk angin, sakit perut, malaria, sakit kepala, batuk, sakit mata, perawatan setelah melahirkan, sakit gigi dan lain sebagainya. Masyarakat umumnya mengobati penyakit yang sering terjadi secara tiba-tiba sehingga masyarakat memanfaatkan tumbuhan untuk meringankan gejala penyakit tersebut. Daftar nama tumbuhan berkhasiat obat dapat dilihat pada Tabel 1

Tabel 2. Spesies tumbuhan obat yang dimanfaatkan oleh masyarakat suku Melayu

Table 2. Medicinal plant species that are utilized by the Malay tribal community

\begin{tabular}{llll}
\hline Khasiat & $\begin{array}{l}\text { Nama Ilmiah (Nama } \\
\text { lokal) }\end{array}$ & $\begin{array}{l}\text { Bagian yang } \\
\text { diambil }\end{array}$ & Famili \\
\hline Amandel & $\begin{array}{l}\text { Elephantopus scaber L. } \\
\text { (tapak leman) }\end{array}$ & Daun & $\begin{array}{l}\text { Asteracea } \\
\text { e }\end{array}$ \\
$\begin{array}{l}\text { Ambeien dan } \\
\text { darah tinggi }\end{array}$ & $\begin{array}{l}\text { Syzigium poleana A. } \\
\text { (daun merah) }\end{array}$ & Daun & Myrtaceae \\
$\begin{array}{l}\text { Ambeien dan } \\
\text { darah tinggi }\end{array}$ & $\begin{array}{l}\text { Morinda citrifolia L. } \\
\text { (Mengkudu) }\end{array}$ & Buah & Rubiaceae \\
Anti bakteri & Phyllanthus urinaria L. & Daun & Euphorbia \\
\hline
\end{tabular}




\begin{tabular}{|c|c|c|c|}
\hline Khasiat & $\begin{array}{l}\text { Nama IImiah (Nama } \\
\text { lokal) }\end{array}$ & $\begin{array}{l}\text { Bagian yang } \\
\text { diambil }\end{array}$ & Famili \\
\hline & (Meniran) & & ceae \\
\hline Anti tumor & $\begin{array}{l}\text { Phaleria macrocarpa } \\
\text { Scheff. Borl (Mahkota } \\
\text { dewa) }\end{array}$ & Buah & $\begin{array}{l}\text { Thymelaea } \\
\text { ceae }\end{array}$ \\
\hline Asam urat & $\begin{array}{l}\text { Anredera cordifolia } \\
\text { Stenis. (daun binahong) }\end{array}$ & Daun & $\begin{array}{l}\text { Baselacea } \\
\mathrm{e}\end{array}$ \\
\hline Asam urat & $\begin{array}{l}\text { Peperomia pellucida } \\
\text { Kunth (Sirih cina) }\end{array}$ & Daun ke akar & $\begin{array}{l}\text { Piperacea } \\
\text { e }\end{array}$ \\
\hline Asma & $\begin{array}{l}\text { Gomphrena globosa L. } \\
\text { (Kenop) }\end{array}$ & Bunga & $\begin{array}{l}\text { Amarantha } \\
\text { ceae }\end{array}$ \\
\hline Asma, rematik & $\begin{array}{l}\text { Cananga adorata } \\
\text { (Lamk) Hook. } \\
\text { (kenanga) }\end{array}$ & Bunga & $\begin{array}{l}\text { Annonace } \\
\text { ae }\end{array}$ \\
\hline Batu empedu & $\begin{array}{l}\text { Sonchus arvensis } \mathrm{L} \text {. } \\
\text { (tempuyung) }\end{array}$ & Daun & $\begin{array}{l}\text { Asteracea } \\
\mathrm{e}\end{array}$ \\
\hline Batu ginjal & $\begin{array}{l}\text { Hemigraphis rependa L. } \\
\text { Hall F. (keji besi) }\end{array}$ & Daun & $\begin{array}{l}\text { Acanthac } \\
\text { eae }\end{array}$ \\
\hline Batu ginjal & $\begin{array}{l}\text { Strobilanthes crispa } \\
\text { Blume. (keji beling) }\end{array}$ & Daun & $\begin{array}{l}\text { Acanthace } \\
\text { ae }\end{array}$ \\
\hline Batuk darah & $\begin{array}{l}\text { Rhoeo discolor A. } \\
\text { (adam hawa) }\end{array}$ & Daun/akar & $\begin{array}{l}\text { Commelin } \\
\text { aceae }\end{array}$ \\
\hline $\begin{array}{l}\text { Bisul dan masalah } \\
\text { kewanitaan }\end{array}$ & $\begin{array}{l}\text { Bougainvillea glabra } \\
\text { Choisy. (Bougenvil) }\end{array}$ & Bunga & $\begin{array}{l}\text { Nyctaginac } \\
\text { eae }\end{array}$ \\
\hline Cacar air & $\begin{array}{l}\text { Ipomea aquatic Forsk. } \\
\text { (kangkung) }\end{array}$ & Daun/batang & $\begin{array}{l}\text { Convolvula } \\
\text { ceae }\end{array}$ \\
\hline Cacingan & $\begin{array}{l}\text { Combretum indicum } \\
\text { (ceguk) }\end{array}$ & Bunga & $\begin{array}{l}\text { Combretac } \\
\text { eae }\end{array}$ \\
\hline Cacingan, demam & $\begin{array}{l}\text { Mimosa pudica L. (Putri } \\
\text { Malu) }\end{array}$ & Akar & Fabaceae \\
\hline Demam & $\begin{array}{l}\text { Andrograpis paniculata } \\
\text { (Burm. F.) Wall. ex } \\
\text { Nees. (Sambiloto) }\end{array}$ & Daun & $\begin{array}{l}\text { Acanthace } \\
\text { ae }\end{array}$ \\
\hline Demam & $\begin{array}{l}\text { Trachyspermum } \\
\text { roxburghianum (DC.) } \\
\text { Craib (Jinten) }\end{array}$ & Daun & Apiaceae \\
\hline Demam & $\begin{array}{l}\text { Jynura procumbens } \\
\text { (Blume. Miq.) (sambung } \\
\text { nyawa) }\end{array}$ & Daun & $\begin{array}{l}\text { Asteracea } \\
\mathrm{e}\end{array}$ \\
\hline Demam & $\begin{array}{l}\text { Kalanchoe pinnata } \\
\text { Lam. (cocor bebek) }\end{array}$ & Daun & $\begin{array}{l}\text { Crassulace } \\
\text { ae }\end{array}$ \\
\hline Demam & $\begin{array}{l}\text { Manihot esculenta C. } \\
\text { (Daun ubi) }\end{array}$ & Daun & $\begin{array}{l}\text { Euphorbia } \\
\text { ceae }\end{array}$ \\
\hline Demam & $\begin{array}{l}\text { Eurycoma longifolia } \\
\text { Jack. (Pasak bumi) }\end{array}$ & Akar & $\begin{array}{l}\text { Simarouba } \\
\text { ceae }\end{array}$ \\
\hline Diabetes & $\begin{array}{l}\text { Tithonia diverfolia } \\
\text { (Hamsl.) (pokok insulin) }\end{array}$ & Daun & $\begin{array}{l}\text { Asteracea } \\
\mathrm{e}\end{array}$ \\
\hline Diabetes & $\begin{array}{l}\text { Orthosiphon aristatus } \\
\text { (Blume) Miq. (Kumis }\end{array}$ & Daun & Lamiaceae \\
\hline
\end{tabular}




\begin{tabular}{|c|c|c|c|}
\hline Khasiat & $\begin{array}{l}\text { Nama IImiah (Nama } \\
\text { lokal) }\end{array}$ & $\begin{array}{l}\text { Bagian yang } \\
\text { diambil }\end{array}$ & Famili \\
\hline & kucing) & & \\
\hline Diabetes & $\begin{array}{l}\text { Antigonon leptopus A. } \\
\text { (Air mata pengantin) }\end{array}$ & Bunga & $\begin{array}{l}\text { Poligonace } \\
\text { ae }\end{array}$ \\
\hline Diabetes & $\begin{array}{l}\text { Gardenia jasminoides } \\
\text { Ellis (kaca piring) }\end{array}$ & Bunga & Rubiaceae \\
\hline Diare & $\begin{array}{l}\text { Psidium guajava Linn. } \\
\text { (Jambu Kelutuk) }\end{array}$ & Daun & Myrtaceae \\
\hline Diare & $\begin{array}{l}\text { Psidium guajava L. } \\
\text { (pucuk jambu batu) }\end{array}$ & Daun & Myrtaceae \\
\hline Eksim & $\begin{array}{l}\text { Nasturtium } \\
\text { microphyllum Boenn. } \\
\text { (selada air) }\end{array}$ & Bunga & $\begin{array}{l}\text { Brassicace } \\
\text { ae }\end{array}$ \\
\hline Flu & $\begin{array}{l}\text { Santalum album L. } \\
\text { (cendana) }\end{array}$ & Bunga & $\begin{array}{l}\text { Santalacea } \\
\text { e }\end{array}$ \\
\hline Gangguan saraf & $\begin{array}{l}\text { Dendrobium } \\
\text { macrophylum (Anggrek) }\end{array}$ & Bunga & $\begin{array}{l}\text { Orchidace } \\
\text { ae }\end{array}$ \\
\hline Ginjal & $\begin{array}{l}\text { Jasminum sambac }(\mathrm{L}) \\
\text { W. Ait (melati) }\end{array}$ & Bunga & Oleaceae \\
\hline Gusi berdarah & $\begin{array}{l}\text { Averrhoa bilimbi L. } \\
\text { (belimbing wuluh) }\end{array}$ & $\begin{array}{l}\text { Daun, batang, } \\
\text { buah }\end{array}$ & $\begin{array}{l}\text { Oxalidacea } \\
\text { e }\end{array}$ \\
\hline Hepatitis & $\begin{array}{l}\text { Selaginella doederleinii } \\
\text { Hieron. (Cakar ayam) }\end{array}$ & Daun & Selaginelle \\
\hline Hipertensi, batuk & $\begin{array}{l}\text { Amomum compactum } \\
\text { soland ex Maton. } \\
\text { (kapulaga) }\end{array}$ & Buah & $\begin{array}{l}\text { Zingiberac } \\
\text { eae }\end{array}$ \\
\hline Keputihan & $\begin{array}{l}\text { Piper ornatum L. (Sirih } \\
\text { merah) }\end{array}$ & Daun & $\begin{array}{l}\text { Piperacea } \\
\text { e }\end{array}$ \\
\hline Luka & $\begin{array}{l}\text { Marumia nemorosa } \\
\text { Blume. (Senuduk) }\end{array}$ & Daun & $\begin{array}{l}\text { Melastoma } \\
\text { taceae }\end{array}$ \\
\hline Luka, sari rapet & $\begin{array}{l}\text { Quercus Iusitanica Oliv. } \\
\text { (Manja Kani) }\end{array}$ & Biji & Fagaceae \\
\hline $\begin{array}{l}\text { Masalah susah } \\
\text { tidur }\end{array}$ & $\begin{array}{l}\text { Myristica fragrans Hout } \\
\text { (pala) }\end{array}$ & Bunga & $\begin{array}{l}\text { Myristicace } \\
\text { ae }\end{array}$ \\
\hline Mata kering & $\begin{array}{l}\text { Apium graveo Lens L. } \\
\text { (daun sop) }\end{array}$ & Daun & Apiaceae \\
\hline $\begin{array}{l}\text { Melancarkan air } \\
\text { seni }\end{array}$ & $\begin{array}{l}\text { Ocicum basilicum L. } \\
\text { (selasih) }\end{array}$ & Daun & Lamiaceae \\
\hline $\begin{array}{l}\text { Melancarkan } \\
\text { aliran darah }\end{array}$ & $\begin{array}{l}\text { Cenntela asiatica L. } \\
\text { Urban. (daun pegage) }\end{array}$ & Daun & $\begin{array}{l}\text { Mackinlaya } \\
\text { ceae }\end{array}$ \\
\hline Melancarkan asi & $\begin{array}{l}\text { Etliengera elatior (Jack } \\
\text { R.M. Smith) } \\
\text { (kecombrang) }\end{array}$ & Bunga & $\begin{array}{l}\text { Zingiberac } \\
\text { eae }\end{array}$ \\
\hline Memar & $\begin{array}{l}\text { Curcuma mangga Val. } \\
\text { (kunyit putih) }\end{array}$ & Umbi & $\begin{array}{l}\text { Zingiberac } \\
\text { eae }\end{array}$ \\
\hline $\begin{array}{l}\text { Menambah nafsu } \\
\text { makan }\end{array}$ & $\begin{array}{l}\text { Talinum paniculatum } \mathrm{L} \text {. } \\
\text { (gingseng jawa) }\end{array}$ & Daun & $\begin{array}{l}\text { Portulacac } \\
\text { eae }\end{array}$ \\
\hline $\begin{array}{l}\text { Mencegah batu } \\
\text { ginjal }\end{array}$ & $\begin{array}{l}\text { Kaempferia galanga L. } \\
\text { (kencur) }\end{array}$ & Umbinya & $\begin{array}{l}\text { Zingiberac } \\
\text { eae }\end{array}$ \\
\hline
\end{tabular}




\begin{tabular}{|c|c|c|c|}
\hline Khasiat & $\begin{array}{l}\text { Nama IImiah (Nama } \\
\text { lokal) }\end{array}$ & $\begin{array}{l}\text { Bagian yang } \\
\text { diambil }\end{array}$ & Famili \\
\hline $\begin{array}{l}\text { Mencegah gigi } \\
\text { berlubang }\end{array}$ & $\begin{array}{l}\text { Piper betle L. (sirih } \\
\text { hijau) }\end{array}$ & Daun & $\begin{array}{l}\text { Piperacea } \\
\text { e }\end{array}$ \\
\hline $\begin{array}{l}\text { Mencegah jantung } \\
\text { koroner }\end{array}$ & $\begin{array}{l}\text { Eleuthrine palmifolia A. } \\
\text { (bawang dayak) }\end{array}$ & Umbinya & Liliaceae \\
\hline Mencegah kanker & $\begin{array}{l}\text { Allium ascalonicum } \mathrm{L} \text {. } \\
\text { (bawang merah) }\end{array}$ & Buah & Alliaceae \\
\hline Mencegah kanker & $\begin{array}{l}\text { Cosmos caudatus } \\
\text { Kunth (kenikir) }\end{array}$ & Daun & $\begin{array}{l}\text { Asteracea } \\
\mathrm{e}\end{array}$ \\
\hline Mencegah kanker & Rosa sp. (mawar) & Bunga & Rosaceae \\
\hline $\begin{array}{l}\text { Mencegah } \\
\text { kemandulan }\end{array}$ & $\begin{array}{l}\text { Ocinum sanctum A. } \\
\text { (daun kemangi) }\end{array}$ & Daun & Lamiaceae \\
\hline $\begin{array}{l}\text { Mencegah kram } \\
\text { otot }\end{array}$ & $\begin{array}{l}\text { Helianthus annus L. } \\
\text { (matahari) }\end{array}$ & Biji & $\begin{array}{l}\text { Asteracea } \\
\mathrm{e}\end{array}$ \\
\hline Mencerahkan kulit & $\begin{array}{l}\text { Cyclea barbata Miers. } \\
\text { (Cincau) }\end{array}$ & Daun & $\begin{array}{l}\text { Menisperm } \\
\text { aceae }\end{array}$ \\
\hline $\begin{array}{l}\text { Mencret, } \\
\text { keracunan }\end{array}$ & $\begin{array}{l}\text { Cocos nucifera L. } \\
\text { (Kelapa) }\end{array}$ & Buah & Arecaceae \\
\hline Mengatasi disentri & $\begin{array}{l}\text { Sesbania grandiflora L. } \\
\text { Pers (turi) }\end{array}$ & Bunga & Fabaceae \\
\hline $\begin{array}{l}\text { Mengatasi } \\
\text { insomnia }\end{array}$ & $\begin{array}{l}\text { Lavandula angustifolia } \\
\text { Mill. (Lavender) }\end{array}$ & Bunga & Lamiaceae \\
\hline $\begin{array}{l}\text { Mengatasi } \\
\text { keputihan }\end{array}$ & $\begin{array}{l}\text { Parameria laevigata } \mathrm{A} . \\
\text { (kayu rapet) }\end{array}$ & Batang & $\begin{array}{l}\text { Apocynace } \\
\text { ae }\end{array}$ \\
\hline $\begin{array}{l}\text { Menghaluskan } \\
\text { kulit }\end{array}$ & $\begin{array}{l}\text { Polianthes tuberosa L. } \\
\text { (Sedap malam) }\end{array}$ & Bunga & Agavaceae \\
\hline $\begin{array}{l}\text { Menghambat } \\
\text { kanker }\end{array}$ & $\begin{array}{l}\text { Mussaenda pubescens } \\
\text { Burm. (Nusa indah) }\end{array}$ & Bunga & Rubiaceae \\
\hline $\begin{array}{l}\text { Menghilangkan } \\
\text { flek hitam }\end{array}$ & $\begin{array}{l}\text { Sauropus androjynus } \\
\text { Merr. (daun katuk) }\end{array}$ & Daun & $\begin{array}{l}\text { Phyllantha } \\
\text { ceae }\end{array}$ \\
\hline $\begin{array}{l}\text { Menghilangkan } \\
\text { jerawat }\end{array}$ & $\begin{array}{l}\text { Chlorophytum } \\
\text { comosum (Lily) }\end{array}$ & Bunga & $\begin{array}{l}\text { Anthericac } \\
\text { eae }\end{array}$ \\
\hline $\begin{array}{l}\text { Menghilangkan } \\
\text { ketombe }\end{array}$ & $\begin{array}{l}\text { Poligonum minus A. } \\
\text { (daun kesum) }\end{array}$ & Daun & $\begin{array}{l}\text { Poligonace } \\
\text { ae }\end{array}$ \\
\hline $\begin{array}{l}\text { Menghitamkan } \\
\text { rambut }\end{array}$ & $\begin{array}{l}\text { Aleurites moluccana L. } \\
\text { Willd. (Kemiri) }\end{array}$ & Buah & $\begin{array}{l}\text { Euphorbia } \\
\text { ceae }\end{array}$ \\
\hline Mengobati encok & $\begin{array}{l}\text { Piper retrofractum Vahl. } \\
\text { (Cabe jawa) }\end{array}$ & Buah & $\begin{array}{l}\text { Piperacea } \\
\mathrm{e}\end{array}$ \\
\hline $\begin{array}{l}\text { Mengobati infeksi } \\
\text { pernapasan }\end{array}$ & $\begin{array}{l}\text { Zingiber officinale Rocs. } \\
\text { (jahe) }\end{array}$ & Buah & $\begin{array}{l}\text { Zingiberac } \\
\text { eae }\end{array}$ \\
\hline $\begin{array}{l}\text { Mengontrol } \\
\text { tekanan darah }\end{array}$ & $\begin{array}{l}\text { Hibiscus rosa-sinensis } \\
\text { L. (kembang sepatu) }\end{array}$ & Bunga & Malfaceae \\
\hline $\begin{array}{l}\text { Meningkatkan } \\
\text { daya ingat otak }\end{array}$ & $\begin{array}{l}\text { Mentha piperita L. } \\
\text { (Daun Mint) }\end{array}$ & Daun & Lamiaceae \\
\hline $\begin{array}{l}\text { Menjaga } \\
\text { kesehatan ginjal }\end{array}$ & $\begin{array}{l}\text { Gnetum gnemon L. } \\
\text { (melinjo) }\end{array}$ & Daun & Gnetaceae \\
\hline $\begin{array}{l}\text { Menjaga } \\
\text { kesehatan ibu } \\
\text { hamil }\end{array}$ & $\begin{array}{l}\text { Pometia pinnata } \\
\text { (Matoa) }\end{array}$ & Buah & $\begin{array}{l}\text { Sapindace } \\
\text { ae }\end{array}$ \\
\hline
\end{tabular}




\begin{tabular}{|c|c|c|c|}
\hline Khasiat & $\begin{array}{l}\text { Nama Ilmiah (Nama } \\
\text { lokal) }\end{array}$ & $\begin{array}{l}\text { Bagian yang } \\
\text { diambil }\end{array}$ & Famili \\
\hline $\begin{array}{l}\text { Menjaga } \\
\text { kesehatan mata }\end{array}$ & $\begin{array}{l}\text { Nephrolepis cordifolia } \\
\text { L. (pakis) }\end{array}$ & Daun & $\begin{array}{l}\text { Dryopterid } \\
\text { aceae }\end{array}$ \\
\hline $\begin{array}{l}\text { Menjaga kulit } \\
\text { sehat }\end{array}$ & $\begin{array}{l}\text { Cymbopogon nardus L. } \\
\text { (serai wangi) }\end{array}$ & Akar & Poaceae \\
\hline $\begin{array}{l}\text { Menurunkan gula } \\
\text { darah }\end{array}$ & $\begin{array}{l}\text { Adenanthera Pavonina } \\
\text { L. (saga) }\end{array}$ & Daun & Fabaceae \\
\hline $\begin{array}{l}\text { Menurunkan } \\
\text { jumlah glukosa }\end{array}$ & $\begin{array}{l}\text { Murraya paniculata (L.) } \\
\text { Jack (Kemuning) }\end{array}$ & Daun/bunga & Rutaceae \\
\hline $\begin{array}{l}\text { Menurunkan } \\
\text { tekanan darah } \\
\text { tinggi }\end{array}$ & $\begin{array}{l}\text { Allium sativum L. } \\
\text { (bawang putih) }\end{array}$ & Umbinya & Alliaceae \\
\hline Meredakan kejang & $\begin{array}{l}\text { Zingiber officinale } \\
\text { Roscoe. (jahe merah) }\end{array}$ & Umbi & $\begin{array}{l}\text { Zingiberac } \\
\text { eae }\end{array}$ \\
\hline $\begin{array}{l}\text { Meredakan nyeri } \\
\text { haid }\end{array}$ & $\begin{array}{l}\text { Curcuma domestica } \\
\text { Val. (kunyit) }\end{array}$ & Umbinya & $\begin{array}{l}\text { Zingiberac } \\
\text { eae }\end{array}$ \\
\hline $\begin{array}{l}\text { Meremajakan sel } \\
\text { tubuh }\end{array}$ & $\begin{array}{l}\text { Hibiscus sabdariffa L. } \\
\text { (rosella) }\end{array}$ & Bunga & Malfaceae \\
\hline Nyeri lambung & $\begin{array}{l}\text { Cymbopogon citratus } \\
\text { (Dc.) (sereh) }\end{array}$ & Batang & Poaceae \\
\hline Obat demam & $\begin{array}{l}\text { Alpinia purpurata L. } \\
\text { (Lengkuas Merah) }\end{array}$ & Umbi & $\begin{array}{l}\text { Zingiberac } \\
\text { eae }\end{array}$ \\
\hline Obat maagh & $\begin{array}{l}\text { Curcuma aeruginosa } \\
\text { Roxb. (Temu hitam) }\end{array}$ & Batang & $\begin{array}{l}\text { Zingiberac } \\
\text { eae }\end{array}$ \\
\hline Obat malaria & $\begin{array}{l}\text { Carica papaya L. } \\
\text { (Betik) }\end{array}$ & Daun & $\begin{array}{l}\text { Caricacea } \\
\text { e }\end{array}$ \\
\hline $\begin{array}{l}\text { Obat sakit perut, } \\
\text { antikanker }\end{array}$ & $\begin{array}{l}\text { Loranthus sp. (Benalu } \\
\text { api) }\end{array}$ & Daun & $\begin{array}{l}\text { Loranthace } \\
\text { ae }\end{array}$ \\
\hline Panu & $\begin{array}{l}\text { Casia alata } \mathrm{L} \text {. } \\
\text { (Gelinggang) }\end{array}$ & Daun & Fabaceae \\
\hline $\begin{array}{l}\text { Pegal-pegal, sakit } \\
\text { kuning }\end{array}$ & $\begin{array}{l}\text { Curcuma xanthorrhiza } \\
\text { Roxb. (Temulawak) }\end{array}$ & Buah & $\begin{array}{l}\text { Zingiberac } \\
\text { eae }\end{array}$ \\
\hline Peluruh air seni & $\begin{array}{l}\text { Euphorbia tirucali L. } \\
\text { (patah tulang) }\end{array}$ & Batang & $\begin{array}{l}\text { Euphorbia } \\
\text { ceae }\end{array}$ \\
\hline $\begin{array}{l}\text { Penambah nafsu } \\
\text { makan }\end{array}$ & $\begin{array}{l}\text { Alpinia galanga L. } \\
\text { (Lengkuas) }\end{array}$ & Umbi & $\begin{array}{l}\text { Zingiberac } \\
\text { eae }\end{array}$ \\
\hline Pencernaan & $\begin{array}{l}\text { Persea americana Mill. } \\
\text { (alpukat) }\end{array}$ & Buah & Lauraceae \\
\hline Pencernaan & $\begin{array}{l}\text { Aloe vera L. (lidah } \\
\text { buaya) }\end{array}$ & Daun & Liliaceae \\
\hline Pereda nyeri & $\begin{array}{l}\text { Nigella sativa L. (jintan } \\
\text { hitam) }\end{array}$ & Buah & $\begin{array}{l}\text { Ranuncula } \\
\text { ceae }\end{array}$ \\
\hline Radang & $\begin{array}{l}\text { Anona squamosa L. } \\
\text { (srikaya) }\end{array}$ & Daun/akar & $\begin{array}{l}\text { Annonace } \\
\text { ae }\end{array}$ \\
\hline Radang lambung & $\begin{array}{l}\text { Sizigium polianthum } \\
\text { (Wight. Walpers.) } \\
\text { (salam) }\end{array}$ & Daun & Myrtaceae \\
\hline Rematik & $\begin{array}{l}\text { Cinnamomum burmanni } \\
\text { Ness. (Kayu Manis) }\end{array}$ & Kulit & Lauraceae \\
\hline
\end{tabular}




\begin{tabular}{|c|c|c|c|}
\hline Khasiat & $\begin{array}{l}\text { Nama IImiah (Nama } \\
\text { lokal) }\end{array}$ & $\begin{array}{l}\text { Bagian yang } \\
\text { diambil }\end{array}$ & Famili \\
\hline Rematik & $\begin{array}{l}\text { Melaleuca leucadendra } \\
\text { L. L. (kayu putih) }\end{array}$ & Batang & Myrtaceae \\
\hline Sakit gigi & $\begin{array}{l}\text { Syzigium aromaticum L. } \\
\text { (cengkeh) }\end{array}$ & Bunga & Myrtaceae \\
\hline Sakit pada gusi & $\begin{array}{l}\text { Artocarpus integer } \\
\text { Thunb. Merr. } \\
\text { (Cempedak) }\end{array}$ & Buah & Moraceae \\
\hline Sakit pinggang & Tulipa sp. (Tulip) & Bunga & Liliaceae \\
\hline Sariawan & $\begin{array}{l}\text { Anacardium occidentale } \\
\text { L. (jambu monyet) }\end{array}$ & Daun & $\begin{array}{l}\text { Anacardiac } \\
\text { eae }\end{array}$ \\
\hline Sariawan & $\begin{array}{l}\text { Citrus aurantifolia } \\
\text { (Christm) (Limau Nipis) }\end{array}$ & Buah & Rutaceae \\
\hline Stroke & $\begin{array}{l}\text { Gynura difaricata L. Dc. } \\
\text { (daun dewa) }\end{array}$ & Daun & $\begin{array}{l}\text { Asteracea } \\
\mathrm{e}\end{array}$ \\
\hline Wasir & $\begin{array}{l}\text { Parkia speciosa Hassk } \\
\text { (Petai) }\end{array}$ & Buah & Fabaceae \\
\hline
\end{tabular}

Beberapa jenis tumbuhan obat yang ditemukan merupakan jenis yang dibudidayakan di luar hutan. Akan tetapi, tidak semua tumbuhan obat dibudidayakan masyarakat, hanya jenis tumbuhan yang mudah ditanam saja yang dibudidayakan oleh masyarakat. Alasan masyarakat membudidayakan tumbuhan obat agar mudah untuk mendapatkannya pada saat masyarakat sangat membutuhkan tumbuhan tersebut. Menurut Sembiring (2015) tumbuhan obat berhabitus pohon tidak dapat tumbuh dengan baik pada kondisi tempat tumbuh yang tidak sesuai dan adanya persaingan yang tinggi antara tumbuhan obat dan tumbuhan yang lain.

Salah satu tumbuhan yang sering digunakan oleh masyarakat suku Melayu adalah daun sejuk atau yang dikenal dengan cocor bebek (Kalanchoe pinnata), karena tumbuhan ini mudah untuk tumbuh dan memiliki banyak khasiat yang dapat mencegah penyakit akan bertambah parah. Cocor bebek (Kalanchoe pinnata) digunakan masyarakat untuk meringankan gejala demam pada anak sehingga tumbuhan ini hampir dimiliki diseluruh rumah masyarakat. Selain mengatasi demam tumbuhan ini juga berkhasiat sebagai obat sakit kepala, batuk, sakit dada, memperlancar haid yang tidak teratur, obat luka, bisul, dan penyakit kulit.

Departemen Kesehatan RI (2000) menjelaskan bahwa kandungan kimia yang terdapat pada daun cocor bebek (Kalanchoe pinnata) adalah sekyawa alkaloid, flavonoid, saponin, dan tanin. Menurut Anonim (2013) masyarakat di Bundelkhand, India menggunakan jus daun segar cocor bebek untuk mengatasi penyakit kuning. Pengolahan daun segar yaitu dihaluskan lalu dijadikan kompres. Ilmu pengobatan cina menggunakan seluruh bagian tanaman yang dipercaya memberi efek dingin untuk menghentikan pendarahan, menghilangkan panas, dan detoksifikasi.

Tumbuhan lain yang banyak digunakan oleh masyarakat Suku Melayu adalah Sirih hijau (Piper betle L.) yang merupakan tumbuhan liana dan menjadi maskot dari Provinsi Kepulauan Riau. Sirih hijau menjadi tumbuhan yang penting dalam kehidupan sehari-hari masyarakat adat dahulunya karena sering digunakan dalam acara-acara adat. Masyarakat Suku Melayu yang sudah lanjut usia mempunyai kebiasaan mengunyah daun sirih hijau (Piper betle L.) yang dipercaya dapat memperkuat gigi mereka diumur yang sudah tua. Manfaat lain sirih hijau adalah sebagai obat untuk masalah kewanitaan seperti meredakan sakit haid, keputihan pada wanita dengan cara direbus. Krismawati (2004) menjelaskan bahwa sirih hijau juga berkhasiat sebagai obat batuk, anti septik dan obat 
kumur. Kandungan yang dimiliki sirih hijau (Piper betle L.) berupa minyak atsiri, khavikol, estragol, euganol, hidroksikavicol dan karvacol.

Bagian tumbuhan obat yang paling banyak digunakan oleh masyarakat adalah daun dan yang paling sedikit adalah biji yang dapat dilihat pada Gambar 2. Zuhud (2009) menjelaskan bahwa penggunaan daun sebagai bahan ramuan obat-obatan dianggap sebagai cara pengolahan yang lebih mudah dibandingkan kulit, batang dan akar. Daun mudah diambil dan memiliki khasiat yang baik dibandingkan dengan bagian-bagian yang lain dan tidak tergantung musim, penggunaan daun juga tidak merusak bagian lainnya karena daun mudah tumbuh kembali dan dapat dimanfaatkan terus-menerus.

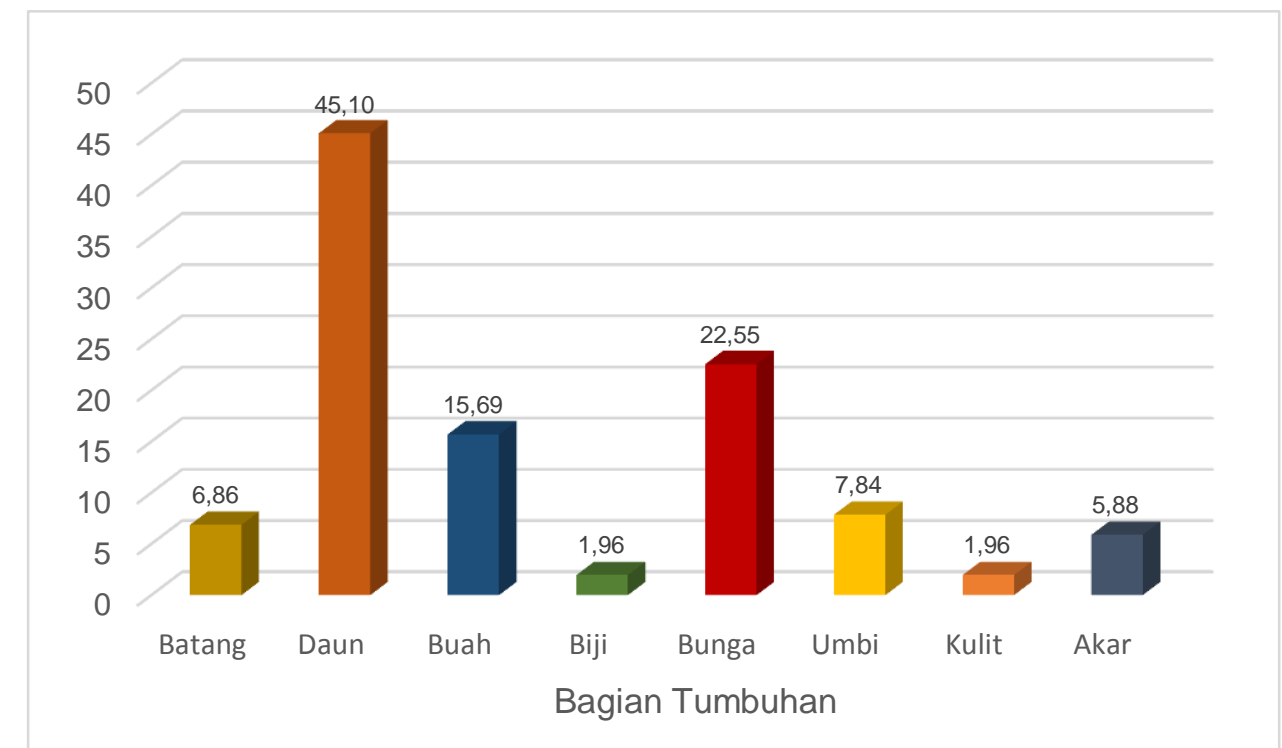

Gambar 2. Persentase bagian tumbuhan yang digunakan sebagai obat Figure 2. Percentage of plant parts used as medicine

Karmilasanti (2011) menjelaskan bahwa tumbuhan yang berkhasiat obat adalah semua jenis tumbuhan yang ada di alam yang mengandung zat-zat kimia tertentu yang terdapat pada bagian-bagian tertentu saja dari tumbuhan seperti akar, batang, daun, dan tunas yang digunakan sebagai ramuan obat untuk penyembuhan suatu penyakit biasanya sebagai pengobatan tradisional. Dalam penelitian Fakhrozi (2009) daun memiliki regenerasi yang tinggi untuk kembali bertunas dan tidak memberi pengaruh terhadap pertumbuhan suatu tanaman meskipun daun merupakan tempat fotosintesis. Penggunaan daun sebagai bagian untuk pengobatan selain tidak merusak spesies tumbuhan obat, bagian daun juga mudah dalam hal pengambilan dan peracikan ramuan obat.

Menurut Handayani (2003) daun merupakan bagian tumbuhan yang banyak digunakan sebagai obat tradisional. Daun umumnya bertekstur lunak karena mempunyai kandungan air yang tinggi (70-80\%). Daun merupakan tempat akumulasi fotosintat yang diduga mengandng unsur-unsur (zat organik) yang memiliki sifat menyembuhkan penyakit. Zat yang banyak terdapat pada daun adalah minyak atsiri, fenol, senyawa kalium, dan klorofil. Klorofil adalah zat yang banyak terdapat pada tumbuhan hijau.

Sastromidjojo (2001) menyatakan Indonesia memiliki jenis tanaman obat yang sangat banyak ragamnya. Tumbuhan yang sering dimanfaatkan daunnya oleh masyarakat untuk menjadi obat diantaranya adalah jambu monyet (Anacardium occidentale), kenanga (Cananga adorata), srikaya (Anona squamosa), Lily (Chlorophytum comosum), seledri (Apium graveo), tapak leman (Elephantopus scaber), pepaya, sirih hijau, jarak pagar, ketepeng cina, keji beling, katuk, salam, dan lainnya. Masyarakat Suku Melayu biasanya mengolah daun dengan cara direbus untuk diminum airnya. 


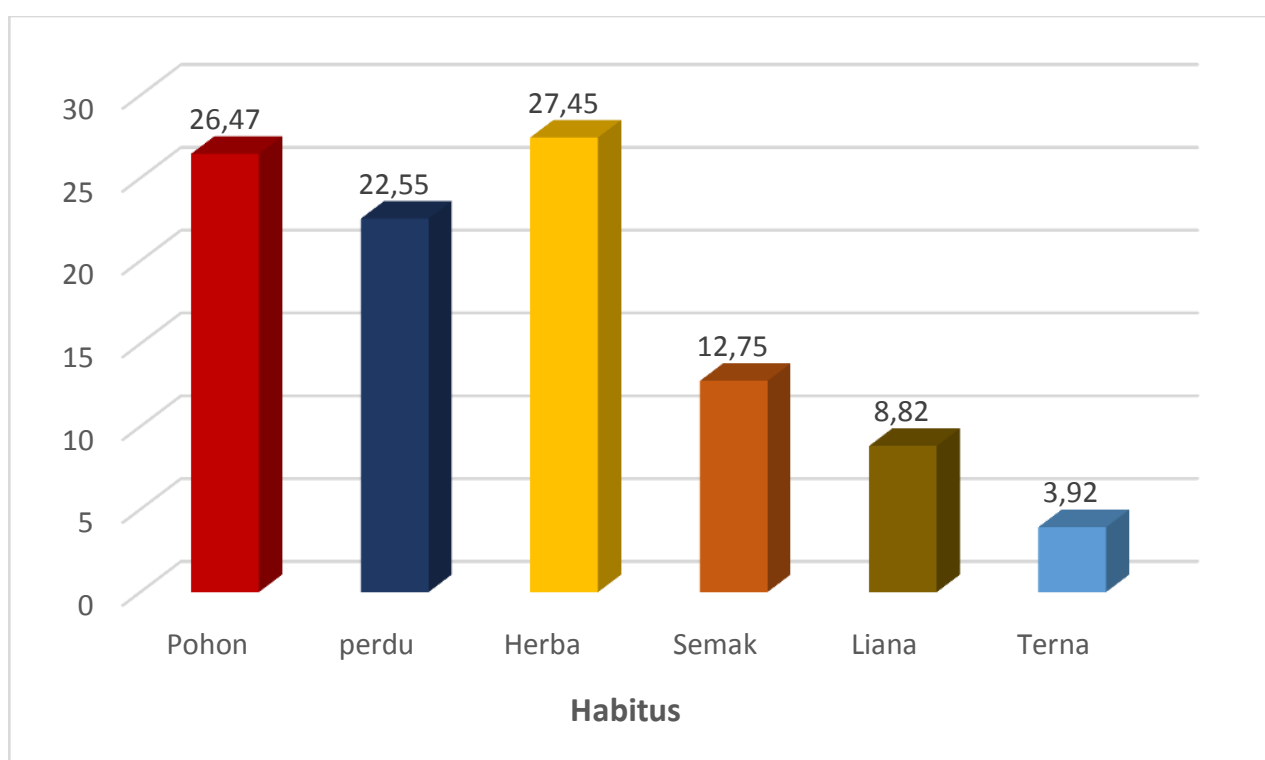

Gambar 3. Persentase Habitus Tumbuhan Obat

Figure 3. Percentage of Medicinal Plant Habitus

Grafik di atas menunjukkan bahwa seluruh masyarakat sering menggunakan tumbuhan herba sebagai tumbuhan obat. Tumbuhan herba memiliki akar dan batang didalam tanah yang tetap hidup meski dimusim kemarau dan akan tumbuh tajuknya yang baru pada musim hujan. Hal ini sesuai dengan penelitian Arizona (2011), pada tumbuhan tingkat herba merupakan tumbuhan yang mudah dibudidayakan dan tidak memerlukan lahan yang luas, cukup di pekarangan untuk melakukan penanaman.

Menurut Sada (2010) tumbuhan herba sering digunakan karena mudah dicari dan mudah ditanam. Tumbuhan herba sangat ditentukan oleh kondisi lingkungan yang mendukung pertumbuhan dan perkembangannya. Habitus yang paling sedikit digunakan oleh masyarakat adalah liana karena masyarakat kurang mengetahui tentang keberadaan tumbuhan liana apa saja yang dapat dimanfaatkan sebagai tumbuhan obat. Salah satu tumbuhan herba yang banyak digunakan yaitu kencur (Kaempferia galanga). Selain digunakan sebagai bumbu masakan kencur juga dapat berkhasiat sebagai obat batuk, gatal-gatal pada tenggorokan, perut kembung, mual, masuk angin, pegal-pegal dan penambah nafsu makan (Miranti, 2009). Kandungan kimia dari rimpang kencur diantaranya terdiri atas saponin, flavonoid, polifenol, dan minyak atsiri yang terdiri atas (etil p-metoksinamat, isobutil $\beta$-2-furilakrilat dan heksil format), derivate monotorpen teroksigenasi serta monoterpen hidrokarbon (Sukari dkk, 2008). Kandungan senyawa metabolit sekunder pada kencur terutama dari golongan flavonoid dan minyak atsiri. Senyawa metabolit sekunder yang dihasilkan oleh tumbuhan Zingiberaceae umumnya dapat menghambat pertumbuhan patogen yang merugikan kehidupan manusia (Nursal dkk, 2006).

Metode pengolahan tumbuhan obat oleh masyarakat Suku Melayu dilakukan dengan cara direbus, direndam, ditumbuk, diseduh, diperas dan tanpa pengolahan. Metode yang paling sering digunakan adalah dengan cara direbus karena dengan direbus masyarakat percaya akan membunuh bakteri yang melekat pada tumbuhan tersebut dan masyarakat lebih suka menggunakannya dengan cara diminum. Pengolahan yang dilakukan dengan cara berbeda memiliki efek yang berbeda pula dalam hal mengobati atau menyembuhkan suatu penyakit, dan perlu diperhatikan pula, misalnya tumbuhan obat yang mengandung racun perlu direbus dengan api kecil dalam waktu sedikit lebih lama, sekitar 3-5 jam untuk mengurangi kadar racunnya (Adnyana, 2012). Meskipun menggunakan obat tradisional relatif kecil memiliki efek samping, tetapi masyarakat di zaman sekarang menyukai pengobatan yang praktis karena mudah didapat dan tidak perlu mengolah dan meramu. 


\section{KESIMPULAN DAN SARAN}

Kearifan tradisional yang ada di masyarakat Suku Melayu didasarkan pada ketergantungan hidup mereka terhadap kelestarian hutan yang ada di sekitar lingkungan hidup mereka. Pemanfaatan tumbuhan obat oleh masyarakat Suku Melayu sebanyak 102 jenis yang tergabung dalam 53 famili. Famili Zingiberaceae merupakan famili yang jenisnya banyak digunakan sebagai tumbuhan obat. Bagian tumbuhan yang paling sering digunakan adalah daun dan habitus tumbuhan yang banyak digunakan adalah herba. Interaksi yang lama antara masyarakat Suku Melayu dan hutan yang ada di sekitar mereka menciptakan suatu keharmonisan, dimana pemanfaatan sumberdaya tumbuhan dengan tetap menjaga kelestarian melalui aturan adat yang ada di masyarakat. Upaya pembinaan perlu dilakukan bagi masyarakat Suku Melayu agar mereka dapat mempertahankan nilai-nilai budayanya khususnya pengetahuan etnobotani yang ada di masyarakat.

\section{DAFTAR PUSTAKA}

Adnyana, M. (2012). Kajian etnobotani tanaman obat oleh masyarakat Kabupaten Bonebolango Provinsi Gorontalo. Gorontalo: FMIPA, Universitas Negeri Gorontalo.

Anonim. (2013). 100 Plus Herbal Indonesia Buku Ilmiah \& Racikan. Depok: PT Trubus Swadaya.

Arizona. D. (2011). Etnobotani dan Potensi Tumbuhan Berguna di Taman Nasional Gunung Ciremai Jawa Barat. Bogor: Fakultas Kehutanan, IPB.

Departemen Kesehatan Republik Indonesia. 2000. Parameter Standar Umum Ekstrak Tumbuhan Obat. Jakarta: Direktorat Jenderal Pengawas Obat dan Makanan, Departemen Kesehatan Republik Indonesia.

Fakhrozi, I. (2009). Etnobotani Masyarakat Suku Melayu Tradisionall di Sekitar Taman Nasional Bukit Tigapuluh (Studi Kasus di Desa Rantau Langsat Kecamatan Batang Gangsal, Kabupaten Indragiri Hulu, Provinsi Riau). Bogor: Fakultas Kehutanan, IPB.

Farida, Y. (2012). Tanaman Obat Nusantara. Yogyakarta: Araska.

Handayani. 2003. Membelah Rahasia Ramuan Madura. Jakarta: Agromedia Pustaka.

Hidayat, A.A. (2009). Metode Penelitian Kebidanan Tehnik Analisis Data. Jakarta: Salemba Medika.

Karmilasanti, S. (2011). Keanekaragaman jenis tumbuhan obat dan pemanfaatannya di kawasan Tane' Olen Desa Setulang Malinau, Kalimantan Timur. Jurnal Penelitian Dipterokarpa. 5(1), 23-38.

Kartikawati, S.M., (2004). Pemanfaatan Sumberdaya Tumbuhan oleh Masyarakat Dayak Meratus di Kawasan Hutan Pegunungan Meratus, Kabupaten Hulu Sungai Tengah. Bogor: Pascasarjana IPB.

Krismawati, A. dan Sabran,M.. (2004). Pengelolaan Sumber Daya Genetik Tanaman Obat Spesifik Kalimantan Tengah. Buletin Plasma Nutfah, 12 (1),17-25.

Mayangsari, A., Indriyanto, Bintoro. dan Surnayanti. (2019). Identifikasi Jenis Tumbuhan Obat di Areal Garapan Petani KPPH Talang Mulya Tahura Wan Abdul Rachman. Jurnal Sylva Lestari, 7(1), 1-9.

Miranti, L. (2009). Pengaruh Konsentrasi Minyak Atsiri Kencur (Kaempferia galangan) dengan Basis Salep Larut Air terhadap Sifat Fisik Salep dan Daya Hambat Bakteri Staphylococcus aureus secara In Vitro. Surakarta: Fakultas Farmasi, Universitas Muhammadiyah Surakarta.

Nawawi, Hadari. (2006). Evaluasi dan Manajemen Kinerja di Lingkungan Perusahaan dan Industri. Yogyakarta: Gadjah Mada University Press.

Nursal, Wulandari, S., Juwita, W.S. (2006). Bioaktifitas ekstrak jahe (Zingiber officinale) dalam menghambat pertumbuhan koloni bakteri Eschericia coli dan Bacillus subtilis. Jurnal Biogenesis, 2(2), 64-66. 
Poerwandari, E. K. (2001). Pendeka-tan Kualitatif untuk Penelitian Perilaku Manusia. Jakarta: Lembaga Pengembanagn Sarana Pengukuran dan Pendidikan Psikologi (LPSP3) Fakultas Psikologi Universitas Indonesia.

Purwanti, Miswan dan Pitopang, R. (2017). Studi etnobotani pada proses ritual adat masyarakat Suku Saluan di Desa Pasokan Kabupaten Tojo Una-una. Jurnal Biocelebes, 11(1), 46-60.

Rijaii, L. (2011). Penentuan kriteria ilmiah potensi tumbuhan obat unggulan Kelompok Bidang Ilmu Kimia Farmasi. Jurnal Kesehatan, 1(2), 64-78.

Sabri, M. (2011). Etnobotani tumbuhan obat dalam kawasan Hutan Wisata Baning Kabupaten Sintang. Pontianak: Fakultas Kehutanan Universitas Tanjung Pura.

Sada, J.T dan Tanjung, R.H.R. (2010). Keragaman tumbuhan obat tradisional di Kampung Nansfori Distrik Supiori Utara, Kabupaten Supiori-Papua. Jurnal Biologi Papua, 2(2), 39-46.

Sari, A., Linda, S., Lovadi, I. (2015). Pemanfaatan tumbuhan obat pada masyarakat Suku Dayak Jangkang Tanjung di Desa Ribau Kecamatan Kapuas Kabupaten Sanggau. Jurnal Protobiont, 4(2), 1-8

Sastroamidjojo, S. (2001). Obat Asli Indonesia Edisi 6. Jakarta: Dian Rakyat.

Sembiring, E. F. Indriyanto dan Duryat. (2015). Keragaman jenis tumbuhan obat di Hutan Pendidikan Universitas Sumatera Utara Kawasan Taman Hutan Raya Tongkoh Kabupaten Karo Sumatera Utara. Jurnal Sylva Lestari, 3(2), 113-122.

Sukari, M.A., Mohd Sharif, A. L. C., Yap, S. W., Tang, B. K., Noeh, M. , Rahman, G. C. L. , Ee, Y. H. , Taufiq, Yap and Yusuf, U. K. (2008). Chemical constituents variatiosns of essential oils from rhizomes of four zingiberaceae species. The Malaysian Journal of Analytical Sciences, 12 (3), 638-644.

Supriyanto, Indriyanto dan Bintoro, A. (2014). Inventarisasi jenis tumbuhan obat di hutan mangrove Desa Margasari Kecamatan Labuhan Maringgai Lampung Timur. Jurnal Sylva Lestari, 2(1), 67-76.

Susiarti, S. (2005). Indigenous knowledge on the uses of medicinal plants by Dayak Benuaq society, West Kutai, East Kalimantan. Journal of Tropical Ethnobiology, 2(1), 52-64.

Syaifuddin., Suryanto, E., Kurniawan, N.M.A. dan Fitriyanti, S. (2015). Etnobiologi tumbuhan hutan berkhasiat obat di Desa Mandiangin Barat Kecamatan Karang Intan Kabupaten Banjar Propinsi Kalimantan Selatan. Balai Penelitian Kehutanan Banjarbaru. 1(2): 1-7.

Zuhud, E, A, M. (2009). Kebijakan Pembangunan Kesehatan Masyarakat Indonesia yang Bhinneka Tunggal Ika dengan Pengembangan Potensi Lokal Ethno-ForestPharmacy (Ethno-Wanafarma) pada Setiap Wilayah Sosial-Biologi Satu-satuan Masyarakat Kecil. Bogor: Departemen Konservasi Sumberdaya Hutan dan Ekowisata, Fakultas Kehutanan, IPB. 